\title{
Piotr Guzowski
}

Warszawa

Radosław Poniat

Białystok

\section{Przeliczniki demograficzne w szacunkach zaludnienia miast w Królestwie Polskim w drugiej połowie XVI wieku*}

Celem artykułu jest prezentacja metod szacowania liczby ludności miast Królestwa Polskiego w drugiej połowie XVI wieku. Ponieważ historycy zajmujący się tą epoką nie dysponują materiałami o charakterze spisów ludności, tak dobrze znanymi badaczom stuleci późniejszych, kalkulacje populacji miejskich muszą być przeprowadzone na podstawie źródeł pośrednich. Choć ich wykorzystanie pozwala jedynie na szacunki obarczone dużym marginesem błędu, kalkulacje takie mogą mimo wszystko okazać się przydatne i pozwolić na określenie rzędu wielkości opisującego zaludnienie ośrodków miejskich ${ }^{1}$. Prezentacja nowych propozycji nie może jednak odbywać się bez odwołania do wcześniejszych dokonań historiografii.

* Przygotowanie publikacji finansowane w ramach programu Ministra Nauki i Szkolnictwa Wyższego pod nazwą „Narodowy Program Rozwoju Humanistyki” w latach 2015-2020, projekt: Atlas historyczny Polski XVI wieku - dopetnienie serii.

${ }^{1} \mathrm{Na}$ znaczenie takiego szacowania w badaniach społeczno-gospodarczych uwage zwracał Andrzej Wyczański, Historyk wobec liczby, [w:] Metody i wyniki. Z warsztatu historyka dziejów spoleczeństwa polskiego, red. Stanisław Kalabiński, wsp. Joanna Hensel, Irena Rychlikowa, Warszawa 1980, s. 11-31. 


\section{Próby wykorzystania szosu}

Podstawą kalkulacji Adolfa Pawińskiego wielkości populacji miast polskich w drugiej połowie XVI wieku były rejestry podatku szos ${ }^{2}$. Obciążenie to, wprowadzone w drugiej połowie XV wieku, było podatkiem od majątku ruchomego i nieruchomego obywateli miejskich ${ }^{3}$. Wykorzystanie go w badaniach demograficznych skrytykowali najpierw Włodzimierz Czerkawski, a później Witold Kula. Mimo tego badacze ci podążyli drogą wyznaczoną przez dziewiętnastowiecznego wydawcę źródeł, modyfikując przyjęty przez niego przelicznik 24 osób na jedną zapłaconą złotówkę szosu, dodając w swoich obliczeniach odpowiednio 50 albo $100 \%$ osób, czyli przeliczając złotówkę podatku na 36 (Kula) lub 48 mieszańców miast (Czerkawski) $^{4}$. Większym zniuansowaniem przeliczników w kalkulacji zaludnienia miast charakteryzowała się praca Egona Vielrose z końca lat pięćdziesiątych $\mathrm{XX}$ wieku, który podzielił miasta na 4 kategorie z przelicznikami wahającymi się od 17 aż do 180 osób na jednego zapłaconego florena ${ }^{5}$. Autor ten posłużył się przy tym danymi o liczbie domów w 35 mazowieckich miastach, wydobytej z lustracji przez Stanisława Pazyrę, wskazującego równocześnie na niedoszacowanie ludności miejskiej $\mathrm{w}$ oparciu jedynie o rejestry szosu ${ }^{6}$. Poszukiwanie odpowiedniego przelicznika wartości szosu na liczbę mieszkańców w dotychczasowych badaniach odbywało się więc dwustopniowo. Najpierw informację o sumie zapłaconej przez miasto zestawiano ze źródłowymi wiadomościami na temat liczby domów w danej miejscowości, a następnie przyjmowano odpowiedni mnożnik liczby mieszkańców na dom, by w ostateczności otrzymać zaludnienie ośrodka miejskiego.

$\mathrm{Z}$ czasem badacze polscy doszli do wniosku, że szos nie nadaje się na punkt wyjścia szacunków liczby mieszkańców miast w drugiej połowie XVI wieku. Irena Gieysztorowa wraz z Tadeuszem Ładogórskim wskazali podstawowe

${ }^{2}$ Adolf Pawiński, Ludność, [w:] Źródła Dziejowe, t. XII. Polska XVI wieku pod względem geograficzno-statystycznym, opr. Adolf Pawiński, t. 1: Wielkopolska, Warszawa 1883, s. 110-116; tenże, Ludność, [w:] Źródła Dziejowe, t. XIV. Polska XVI wieku pod względem geograficzno-statystycznym, opr. Adolf Pawiński, t. 3: Małopolska, Warszawa 1886, s. 45-53.

${ }^{3}$ Stefan Weyman, Pierwsze ustawy pogtównego generalnego w Polsce na tle ówczesnego systemu podatkowego, „Roczniki Dziejów Społecznych i Gospodarczych” 18, 1956, s. 18. Szacuje się, że w dużych miastach obywatele stanowili ok $25 \%$ wszystkich mieszkańców - Stanisław Gierszewski, Obywatele miast Polski przedrozbiorowej. Studium źródłoznawcze, Warszawa 1973, s. $31-32$.

${ }^{4}$ Włodzimierz Czerkawski, Metoda badania zaludnienia Polski w XVI wieku, ,Sprawozdania z Czynności i Posiedzeń Akademii Umiejętności” 2, 1897, s. 12; Witold Kula, Stan i potrzeby badań nad demografia historyczna dawnej Polski (do początków XIX wieku), „Roczniki Dziejów Społecznych i Gospodarczych" 13, 1951, s. 64.

${ }^{5}$ Egon Vielrose, Ludność Polski od X do XVIII wieku, „,Kwartalnik Historii Kultury Materialnej" 5, 1957, nr 1, s. 37-42.

${ }^{6}$ Stanisław Pazyra, Studia z dziejów miast na Mazowszu od XIII do początków XX wieku, Lwów 1939, s. 281-283. 
wady tego źródła: „Początkowa stopa opodatkowania 1 grosz od grzywny majątku wzrasta dwukrotnie na przełomie XV i XVI w., a ustalony na tej podstawie wymiar szosu dla każdego z miast ściągany jest przy następnych poborach w 1/2,2/3, 1, 1 1/2, 1 2/3 lub dwukrotnym (od 1563 r. już stale 2-krotnym, dupla) przemnożeniu przez cały wiek XVI. Podatek ten w II połowie XVI w. obciążał wyłącznie właścicieli nieruchomości według wewnętrznego rozbicia przez władze miejskie globalnej sumy na pojedynczych właścicieli. Geneza wymiaru szosu oraz wieloletnie zryczałtowanie decydują o tym, że nie może on stanowić miernika demograficznego"7. We Wstępie do demografii staropolskiej słusznie więc zwrócono uwagę, że „Głównym zatem oparciem miejskich szacunków ludnościowych pozostaje liczba domów, znana dla części miast królewskich i kościelnych z lustracji i inwentarzy, oraz niekiedy z abiurat po pożarach miast szlacheckich"8.

\section{Domy a liczba ludności}

Stanisław Pazyra, wykonujący kalkulacje ludności miejskiej Mazowsza w drugiej połowie XVI wieku, doszedł do wniosku, że na jeden dom przypadały średnio dwie sześcioosobowe rodziny, a więc przyjął przelicznik aż 12 osób na dom ${ }^{9}$. Mniejszego o połowę przelicznika - 6 - używał z kolei Aleksander Jabłonowski w opracowaniach kolejnych tomów Źródeł Dziejowych ${ }^{10}$ dotyczących Podlasia, a także przelicznika 5 w przypadku Rusi Czerwonej ${ }^{11}$. W powojennej historiografii można spotkać jeszcze inne przeliczniki. Egon Vielrose używał przelicznika 6 osób na dom w siedemnastym stuleciu ${ }^{12}$, podobnie jak Zenon Guldon obliczając zaludnienie Kujaw w drugiej połowie XVI wieku ${ }^{13}$. Z kolei Józef Morzy, zajmując się Wielkim Księstwem Litewskim w drugiej połowie XVII wieku, zastosował przelicznik wynoszący 8 , choć uznał go za typowy raczej dla

\footnotetext{
${ }^{7}$ Irena Gieysztorowa, Tadeusz Ładogórski, $W$ sprawie nowych badań nad zaludnieniem dawnej Polski, „Kwartalnik Historii Kultury Materialnej” 6, 1958, nr 1-2, s. 54-55.

${ }^{8}$ Irena Gieysztorowa, Wstęp do demografii staropolskiej, Warszawa 1976, s. 184.

${ }^{9}$ S. Pazyra, Studia [6], s. 280.

${ }^{10}$ Aleksander Jabłonowski, Ludność, [w:] Źródła Dziejowe, t. XVII. Polska XVI wieku pod względem geograficzno-statystycznym, opr. Aleksander Jabłonowski, t. 6, cz. 3, Podlasie, Warszawa 1910, s. 90-95.

${ }^{11}$ Aleksander Jabłonowski, Ludność, [w:] Źródta Dziejowe, t. XVIII. Polska XVI wieku pod względem geograficzno-statystycznym, opr. Aleksander Jabłonowski, t. 7, cz. 2, Ziemie Ruskie, Ruś Czerwona, Warszawa 1903, s. 194.

${ }^{12}$ E. Vielrose, Ludność [5], s. 15.

${ }^{13}$ Zenon Guldon, Zaludnienie miast kujawskich w XVI i pierwszej połowie XVII wieku, Prace Komisji Historii Bydgoskiego Towarzystwa Naukowego, Prace Wydziału Nauk Humanistycznych, Seria C, 1963, nr 2, s. 55.
} 
małych miasteczek, a nie dużych miast ${ }^{14}$. Stanisław Aleksandrowicz, obliczając zaludnienie miast litewskich i białoruskich, ale w okresie wcześniejszym, stosował mnożnik równy 7, zaś określając stan populacji miast podlaskich - współczynnik 6 osób na dom ${ }^{15}$. Irena Gieysztorowa w mazowieckim tomie Atlasu $\mathrm{Hi}$ storycznego Polski zastosowała przeliczniki $6-7^{16}$, ale w innych opracowaniach tej serii liczono 9 osób na dom miejski ${ }^{17}$.

Dotychczasowa literatura nie dopracowała się więc jednolitego przelicznika i nawet $\mathrm{w}$ odpowiednim fragmencie podręcznika Wstęp do demografii staropolskiej, zwykle bardzo precyzyjna autorka zauważyła: „Stosowane dotychczas w badaniach polskich wskaźniki 6-7 mieszkańców na dom, należałoby nieco podnieść, zależnie od rangi ośrodka miejskiego, ocenianej w przybliżeniu na podstawie całości zachowanej dokumentacji”'18.

Wobec słabości podstawy źródłowej dotyczącej XVI wieku, która uniemożliwia badaczom sformułowanie przeliczników mogących posłużyć do szacowania zaludnienia miast w sposób wykraczający poza hipotezy poparte intuicją, prowadzone poniżej rozważania oparte zostaną na materiale późniejszym, dotyczącym przede wszystkim XVIII stulecia. Choć decyzja taka może być uznana za kontrowersyjną, ma ona kilka istotnych zalet. Po pierwsze, charakterystyczny dla drugiej połowy XVIII wieku rozwój administracji państwowej oraz wytwarzanej przez nią sprawozdawczości zaowocował powstaniem stosunkowo licznych i zróżnicowanych źródeł. Co ważne, w wielu przypadkach starano się w nich rejestrować nie tylko podatników lub obywateli poszczególnych miast, ale ogół zamieszkującej je ludności. Po drugie, często pojawiają się w nich pełne dane na temat zabudowy mieszkalnej, w tym także domów należących do grup ze zwyczajnych podatków miejskich wyłączonych. Po trzecie, za pomocą materiałów

${ }^{14}$ Józef Morzy, Kryzys demograficzny na Litwie i Białorusi w II połowie XVII wieku, Poznań 1965, s. 129-132, 288-305.

${ }^{15}$ Stanisław Aleksandrowicz, Zaludnienie miasteczek Litwy i Białorusi w XVI i pierwszej połowie XVII wieku, „Roczniki Dziejów Społecznych i Gospodarczych” 27, 1965, s. 55; Stanisław Aleksandrowicz, Powstanie i rozwój miast województwa podlaskiego (XV-1 pot. XVII w. ), „Acta Baltico-Slavica" 1, 1964, s. 150-151.

${ }^{16}$ Irena Gieysztorowa, Charakter $i$ wielkość osad, [w:] Atlas Historyczny Polski, t. 7: Mazowsze w połowie XVI wieku, red. Władysław Pałucki, część II: Komentarz, indeksy, Warszawa 1973, s. $77-87$.

${ }^{17}$ Anna Dunin-Wąsowicz, Charakter i wielkość osiedli, [w:] Atlas Historyczny Polski. Województwo sandomierskie $w$ drugiej połowie XVI wieku, red. Władysław Pałucki, część II: Komentarz, indeksy, Warszawa 1993, s. 81; Krzysztof Chłapowski, Charakter i wielkość osiedli, [w:] Atlas Historyczny Polski. Województwo sieradzkie i województwo tęczyckie $w$ drugiej potowie XVI wieku, cz. 2, Warszawa 1998, s. 53; Jarosław Suproniuk, Charakter i wielkość osiedli, [w:] Atlas Historyczny Polski. Województwo krakowskie w drugiej połowie XVI wieku, red. Henryk Rutkowski, część II: Komentarz, indeksy, Warszawa 2008, s. 71.

${ }^{18}$ I. Gieysztorowa, Wstęp [8], s. 182. 
takich opisać można wiele ośrodków miejskich, minimalizując w ten sposób zarzut niereprezentatywności analizowanej miejscowości dla pozostałych miast.

Oczywiście, wykorzystanie danych pochodzących z wieku XVIII do opisywania wcześniejszych stuleci zasadne będzie jedynie przy założeniu, że w ciągu ponad dwustu lat nie doszło do istotnych zmian w formach życia miejskiego, w tym przede wszystkim w strukturze ich zabudowy, sposobie jej wykorzystywania przez mieszkańców oraz wielkości rodziny. Wydaje się, że założenie takie można obronić w przypadku znacznej części mniejszych ośrodków miejskich, których rozwój, jeśli za dobrą monetę przyjąć często spotykane w literaturze opinie, w wiekach XVI i XVII miał być ograniczony przez szlacheckie ustawodawstwo. W sytuacji dotykającego mieszczaństwo kryzysu społeczno-polityczno-ekonomicznego trudno spodziewać się, aby większość jego przedstawicieli była w stanie dokonywać istotnych inwestycji prowadzących do poważnych zmian w zabudowie, co z kolei mogłoby się przełożyć na wzrost przeciętnego zaludnienia domów. Generalna aprobata takiego stwierdzenia nie oznacza, że w Rzeczypospolitej nie istniały ośrodki przeżywające w opisywanych stuleciach okresu gwałtownego rozwoju. Miasta takie jak Gdańsk czy Warszawa, w których dokonywano znacznych inwestycji ${ }^{19}$, fundowano nowe instytucje $\mathrm{i}$ w poważnym stopniu zmieniano strukturę zabudowy mieszkalnej, z całą pewnością nie popadły w stagnację. Wydaje się jednak, że wiele innych ośrodków, w tym zwłaszcza mniejszych, jeśli nawet doświadczało okresów prosperity, to wciąż charakteryzowało się względnie stałymi formami zabudowy oraz sposobami jej wykorzystania. Można więc mieć nadzieję, że wyniki uzyskane dzięki analizie takich miast w przybliżeniu oddawać będą sytuację panującą w stuleciach wcześniejszych.

Powyższe uwagi, skupiające się przede wszystkim na zaludnieniu budynków, wynikają z faktu, że to właśnie dane dotyczące zabudowy wydają się dawać największe szanse na opracowanie przeliczników służących szacowaniu ludności XVI-wiecznych miast. Choć wymienić tu można kilka innych potencjalnych wskaźników, to wydaje się, że to właśnie informacje dotyczące budynków są najpowszechniej dostępne i wymagają najmniejszej liczby dodatkowych założeń. Nie oznacza to jednak, iż szacowanie zaludnienia miast w oparciu o liczbę zarejestrowanych w źródłach domów nie wiąże się z możliwością popełnienia błędów. Podstawowe znaczenie będzie tu miało przede wszystkim określenie charakteru występującej w danym ośrodku zabudowy. W zależności od tego, czy dominowały tam proste drewniane domy niewiele różniące się od tych spotykanych

\footnotetext{
${ }^{19}$ Obok inwestycji takich jak pałace lub klasztory, istotną rolę pełnić tu też mogły przekształcenia bardziej klasycznej zabudowy mieszkalnej. Należały do niej chociażby, dobrze znane w odniesieniu do Gdańska, czynszowe domy wielorodzinne, w których zamieszkiwało obok siebie nawet po kilkanaście rodzin - por. Ewa Barylewska-Szymańska, Od piwnic po strych. Wnętrza domów gdańskich drugiej połowy XVIII wieku, Warszawa-Gdańsk 2015, s. 41-44.
} 
na wsiach, czy raczej duże kamienice mieszczańskie, przeciętna liczba mieszkańców przypadających na pojedynczy budynek podlegać musiała przecież znacznym wahaniom. Na potwierdzenie tej tezy przywołać można dane zgromadzone przez Konrada Wnęka, który wiele uwagi poświęcił przestrzeni i zabudowie nowożytnego Krakowa ${ }^{20}$. Jednym z wykorzystywanych przez niego źródeł jest pochodzący z 1791 roku spis zabudowań ${ }^{21}$. Cechą charakterystyczną tego dokumentu jest występowanie w nim, obok tabelarycznego zestawienia podstawowych rodzajów występujących w Krakowie budynków, danych dotyczących liczby zamieszkujących je ludzi. W ten sposób dokładnie określić można zaludnienie każdego domu w powiązaniu z jego typem. Podstawowe miary statystyczne opisujące takie zależności zaprezentowane zostały w tabeli 1. Widoczne w niej określenia tylko w części przypadków powtarzają terminy występujące w źródle. Tak więc, choć podobnie jak w spisie, budynki murowane podzielone zostały na znajdujące się w centrum miasta i na dalszych ulicach, to pominięte zostały tu dalsze rozróżnienia związane ze stanem społecznym właściciela. Z kolei kategoria ,instytucje” obejmuje między innymi budynki klasztorne, szpitalne oraz służące na potrzeby edukacji, które to grupy w tabelach spisowych traktowano rozłącznie. Dla prowadzonych tu analiz podziały takie nie mają jednak istotnego znaczenia. W ostatniej kolumnie tabeli podana została informacja o odsetku budynków, które według spisu miały być niezamieszkałe. Z powodu występowania „pustostanów” wyliczono dwie średnie zaludnienia: w przypadku pierwszej z nich liczba mieszkańców dzielona była przez ogół budynków danej kategorii, gdy tymczasem druga uwzględniała jedynie domy posiadające lokatorów.

Analiza danych zawartych w tabeli 1 wskazuje przede wszystkim na wyraźne różnice zaludnienia ze względu na typ budynku. Domy drewniane okazują się charakteryzować najniższą średnią liczbą mieszkańców ${ }^{22}$. Dwukrotnie wyższy wynik zaobserwować można w przypadku kamienic. Drobne różnice między tymi położonymi w Rynku a znajdującymi się w ulicach mają mniejsze znaczenie i nie są istotne statystycznie. Co niezaskakujące, wyższe wartości obserwować można w przypadku instytucji oraz pałaców. Trzeba też jednak zauważyć, że charakteryzują się one również większym zróżnicowaniem. Ponieważ zabudowa Krakowa, w tym zwłaszcza jego części położonej w obrębie murów, musiała

\footnotetext{
${ }^{20}$ Konrad Wnęk, Wtasność nieruchomości w Krakowie w połowie XIX w. Studia nad stałym katastrem galicyjskim, Kraków 2011.

${ }^{21}$ Archiwum Narodowe w Krakowie, sygn. IT 155. Spisem objęty został jedynie Kraków w obrębie murów miejskich. Brak tu więc danych dotyczących Kazimierza, Kleparza oraz przedmieść. Wersję elektroniczną spisu opracował i udostępnił autorom dr hab. Konrad Wnęk.

${ }^{22}$ Średnie zaludnienie budynków drewnianych różni się w sposób istotny od wszystkich pozostałych rodzajów zabudowy z wyłączeniem pałaców, które charakteryzują się dużym zróżnicowaniem liczby mieszkańców połączonym z małą liczebnością tej kategorii. Prawidłowości te dotyczą widocznych w tabeli średnich liczonych na oba sposoby.
} 
Tabela 1. Zaludnienie domów w Krakowie w roku 1791 w podziale ze względu na rodzaj zabudowy

\begin{tabular}{lccccc}
\hline \multicolumn{1}{c}{ Typ budynku } & $\begin{array}{c}\text { Średnie } \\
\text { zaludnienie }\end{array}$ & $\begin{array}{c}\text { Odchylenie } \\
\text { standardowe }^{\text {a }}\end{array}$ & $\begin{array}{c}\text { Średnie } \\
\text { zaludnienie } \\
\text { zamieszkanych }\end{array}$ & $\begin{array}{c}\text { Liczba } \\
\text { budynków }\end{array}$ & $\begin{array}{c}\text { Procent } \\
\text { budynków nie- } \\
\text { zamieszkanych }\end{array}$ \\
\hline $\begin{array}{l}\text { Drewniane } \\
\text { Murowane }\end{array}$ & 8,3 & 7,95 & 9,2 & 83 & 9,6 \\
$\begin{array}{l}\text { w ulicach } \\
\text { Murowane }\end{array}$ & 16 & 10,81 & 16,6 & 406 & 3,9 \\
w Rynku & 16,9 & 12,43 & 16,9 & 54 & 0 \\
Instytucje & 25,3 & 20,23 & 27,7 & 72 & 8,3 \\
Pałace & 21,1 & 25,05 & 29,6 & 7 & 28,6 \\
\hline
\end{tabular}

${ }^{a}$ Wyliczone dla budynków zamieszkanych i niezamieszkanych.

Źródło: Archiwum Narodowe w Krakowie, sygn. IT 155.

dość poważnie odbiegać od tej spotykanej w mniejszych ośrodkach, w kontekście prowadzonych tu analiz wagę należy przywiązywać nie do zawartych w tabeli dokładnych wartości liczbowych, ale raczej do zachodzących między nimi relacji. Okazuje się, że domy drewniane miały przeciętnie wyraźnie mniej mieszkańców niż murowane, zaś jeszcze wyższe średnie występowały w przypadku pałaców i instytucji ${ }^{23}$. Obserwacja taka prowadzi z kolei do wniosku, iż większość polskiej literatury dotyczącej zabudowy nowożytnych miast może mieć tylko ograniczoną przydatność do szacowania przeciętnego zaludnienia domów. $\mathrm{Z}$ oczywistych przyczyn historycy sztuki, architektury i kultury materialnej najwięcej uwagi poświęcili bowiem budynkom murowanym. Niestety, konstrukcje tego typu występowały przede wszystkim w największych i najbogatszych miastach, a stanowiły rzadkość w małych miejscowościach ${ }^{24}$. To jednak właśnie takie, często na wpół wiejskie ośrodki stanowiły zdecydowaną większość miast i miasteczek Królestwa Polskiego i Rzeczypospolitej.

${ }^{23}$ Podobnego zdania jest Mieczysław Kędelski zajmujący się populacją Poznania - Rozwój demograficzny Poznania w XVIII i na początku XIX wieku, Poznań 1992, s. 75.

${ }^{24}$ Nawet w najbardziej rozwiniętej Warszawie (lewobrzeżnej) w latach 1797-1798 na 3181 domów zaledwie 33,9\% było murowanych. Zob. Samuel Szymkiewicz, Warszawa na przełomie XVIII i XIX w. w świetle pomiarów i spisów, Warszawa 1959, s. 96; Hanna Szwankowska, Drewniana zabudowa mieszkaniowa Warszawy Oświecenia, [w:] Warszawa XVIII wieku, z. 1, Warszawa 1972, s. 191-228. 
Tabela 2. Zaludnienie domów w wybranych miastach w roku 1791 i 1794

\begin{tabular}{lcccccc}
\hline \multicolumn{1}{c}{ Miasto } & Średnia & Mediana & $\begin{array}{c}\text { Klasyczny } \\
\text { współczynnik } \\
\text { zmienności }\end{array}$ & $\begin{array}{c}\text { Pozycyjny } \\
\text { współczynnik } \\
\text { zmienności }\end{array}$ & $\begin{array}{c}\text { Liczba } \\
\text { ludności }\end{array}$ & $\begin{array}{c}\text { Liczba } \\
\text { budynków }\end{array}$ \\
\hline Warszawa $^{\mathrm{a}}$ & 20 & 15 & 80,1 & 89 & 13133 & 656 \\
Kraków $^{\mathrm{b}}$ & 15,1 & 13 & 75,3 & 68,4 & 5404 & 358 \\
Miechów & 8,6 & 7 & 67,9 & 42,4 & 1374 & 159 \\
Grodno & 7,2 & 5 & 128,1 & 59,3 & 6219 & 862 \\
Wieluń & 6,1 & 5 & 68,5 & 59,3 & 1127 & 186 \\
Radziejów & 5,4 & 5 & 48,9 & 29,7 & 563 & 104 \\
Olkusz & 5,1 & 5 & 51,2 & 59,3 & 460 & 91 \\
Praszka & 5 & 5 & 42,1 & 29,7 & 625 & 124 \\
\hline
\end{tabular}

a Parafia św. Krzyża, ${ }^{\text {b }}$ Parafia Mariacka

Źródło: AGAD, Akta Komisji Porządkowej Cywilno-Wojskowej powiatu radziejowskiego 4; AGAD, Akta Komisji Porządkowej Cywilno-Wojskowej ziemi wieluńskiej i powiatu ostrzeszowskiego 4; AGAD, Varia Grodu Warszawskiego 25; AN w Krakowie, IT 180, 182; Spis mieszkańców Grodna z 1794 r., opr. Jerzy Urawnowicz, [w:] Grodno w XVIII wieku. Miasto i ludność, red. Andrzej Woltanowski, Jerzy Urwanowicz, Białystok 1997, s. 61-171.

Na poważne różnice w średnim zaludnieniu budynków w dużych i małych miastach wskazują także dane zawarte w tabeli 2. Jej podstawę źródłową stanowią spisy komisji cywilno-wojskowych lub podobne do nich materiały z lat 90 . XVIII wieku. Ponieważ sporządzano je według domów, bez trudu można za ich pomocą wyliczyć zaludnienie zamieszkałych budynków. Brak tu natomiast danych dotyczących „pustostanów”. Można się jedynie domyślać, że ich uwzględnienie obniżyłoby nieco obserwowane w tabeli wartości. Co niezaskakujące, najwyższe średnie uzyskano w przypadku spisów dotyczących warszawskiej parafii św. Krzyża i krakowskiej parafii Mariackiej. Wynik taki stanowi rezultat specyficznej na tle innych miast zabudowy, w znacznym stopniu murowanej, często też powiązanej z różnego rodzaju instytucjami ${ }^{25}$. Tymczasem miejscowości mniejsze, liczące w niektórych przypadkach poniżej tysiąca mieszkańców, charakteryzują się wyraźnie niższymi średnimi. Okazuje się, że nawet drewniane domy w Krakowie miały zaludnienie przeciętnie wyższe od obserwowanego w Grodnie i małych miastach! Wyjątkiem nie jest tu nawet Miechów, jeśli weźmiemy pod uwagę fakt, że dane ze spisów ludności dotyczą wyłącznie budynków zamieszkanych i pomijają puste.

\footnotetext{
${ }^{25}$ Nie można jednak twierdzić, że wyłącznie skupienie w Warszawie i Krakowie szpitali czy klasztorów doprowadziło do wysokich średnich arytmetycznych. Choć współczynniki zmienności są tu wyższe niż w przypadku mniejszych ośrodków (z wyjątkiem specyficznego, pełniącego ważne funkcje administracyjne Grodna), to wciąż nie odbiegają one w spektakularny sposób od wartości obserwowanych w Miechowie czy Olkuszu. Choć więc instytucje i pałace zawyżają tu średnie, to nie tylko one odpowiadają za przewagę przeciętnego zaludnienia w dużych miejscowościach.
} 
Wykres 1. Zaludnienie domów w wybranych miastach w roku 1791 i 1794

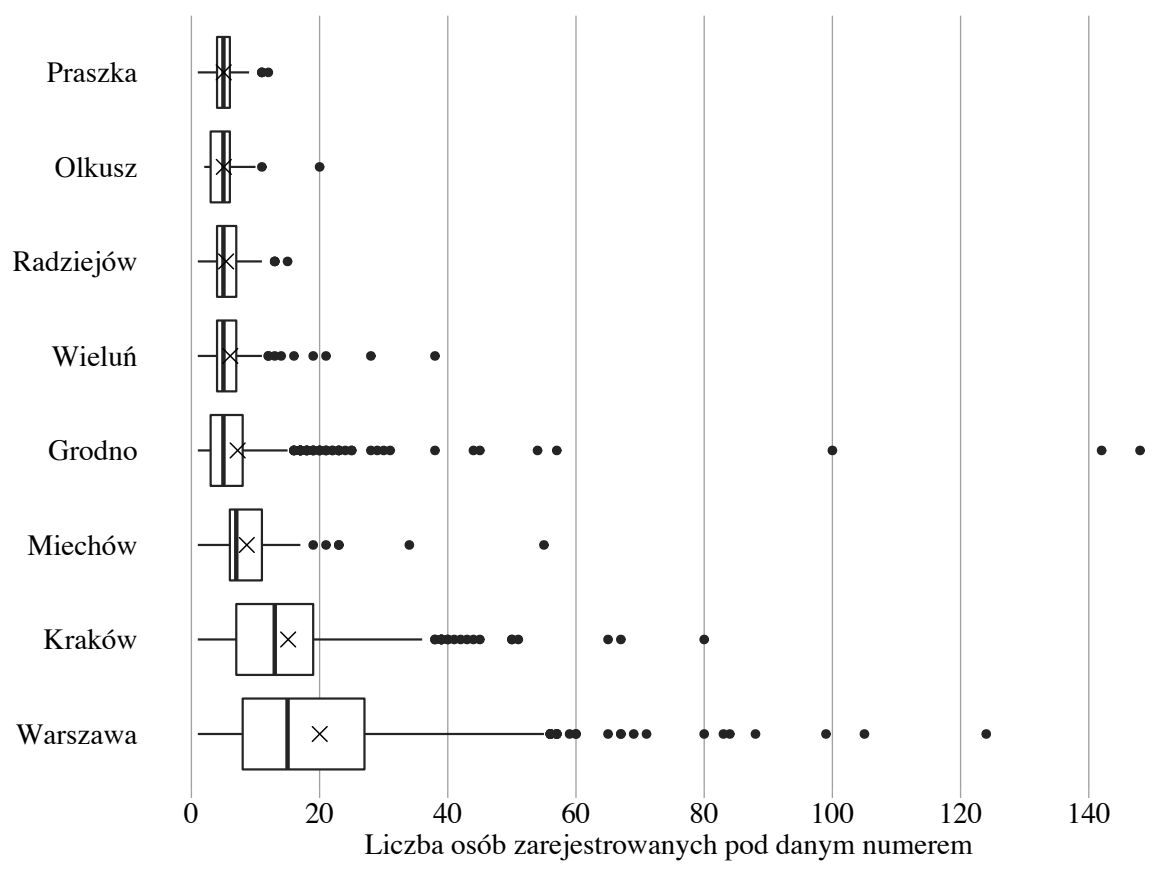

Źródło: patrz tabela 3.

Widoczne na wykresie 1 rozkłady zaprezentowane przy pomocy pudełek opisujących miary pozycyjne wskazują na względną jednorodność zaludnienia domów w miastach najmniejszych, w których tylko sporadycznie pojawiały się budynki zamieszkałe przez więcej niż 10 osób. Jest to pośredni dowód na drewnianą zabudowę miast takich jak Praszka, Olkusz czy Radziejów. Ośrodki ludniejsze charakteryzują się już większym zróżnicowaniem zaludnienia budynków. Zwłaszcza w przypadku Warszawy i Krakowa łatwo dostrzec, że w ponad 75\% zarejestrowanych tam domów mieszkało przeciętnie więcej osób niż w niemal wszystkich budynkach znajdujących się w miastach najmniejszych. Zróżnicowanie takie wynikać musi ze wspomnianych już wcześniej odmiennych cech zabudowy miejskiej. Uwagę zwraca także specyfika Grodna, w którym obok znacznej liczby domów o niskim zaludnieniu pojawiają się również budynki zamieszkiwane nawet przez ponad 100 osób. Skutkuje to poważnymi dysproporcjami między medianą (na wykresie zgodnie z konwencją zaznaczoną za pomocą pogrubionej linii) a średnią arytmetyczną (krzyżyk). Występowanie w Grodnie takich budynków, należących do instytucji religijnych i państwowych, wskazuje na znaczenie wiedzy o występowaniu w danym mieście klasztorów i pałaców 
dla szacowania populacji. W przypadku mniejszych ośrodków nawet pojedynczy, ale znaczący klasztor może w poważnym stopniu zmieniać łączne zaludnienie miasta.

Przedstawione tu analizy, wskazujące na powiązanie przeciętnego zaludnienia domów $\mathrm{z}$ dominującą $\mathrm{w}$ danym mieście zabudową i pośrednio wielkością danego ośrodka, oparte są niestety na dość skromnej próbie, dotyczącej tylko kilku miejscowości, w części przypadków dość zresztą specyficznych (Warszawa, Kraków, Grodno). Szansę na znaczne powiększenie wykorzystywanej próby oraz włączenie do niej pełniejszej reprezentacji ośrodków mniejszych dają dopiero pochodzące z końca XVIII wieku tzw. tabele miast. Źródła tego typu, opracowywane często na zlecenie władz zaborczych, zainteresowanych dokładnym opisem nowych nabytków terytorialnych, mają masowy charakter i zawierają informacje dotyczące zaludnienia oraz zabudowy. Spośród kilku dostępnych zbiorów tego typu, postanowiliśmy wykorzystać zestawienia wytworzone przez władze austriackie $^{26}$. Najważniejsze $\mathrm{z}$ zawartych $\mathrm{w}$ nich informacji zostały wydane niedawno jako załącznik do książki Łukasza Jewuły ${ }^{27}$ i właśnie na tym zestawieniu oparte zostaną dalsze analizy. W tabeli 3 odnaleźć można podstawowe miary statystyczne opisujące zaludnienie domów w miastach galicyjskich w roku 1787. Dotyczą one w sumie 248 miejscowości ${ }^{28}$. Choć pojawiają się tu pewne braki danych, baza opisuje zdecydowaną większość miast galicyjskich. W dwóch ostatnich kolumnach tabeli dołączone zostały podstawowe dane pochodzące $\mathrm{z}$ roku 1824, które służyć mają celom porównawczym. Ponieważ wcześniejsze analizy wskazały na związek przeciętnego zaludnienia domu z wielkością miejscowości, opisywane tu miasta podzielone zostały na 6 grup wyróżnionych ze względu na liczbę znajdujących się w nich budynków, co w przybliżeniu oddaje także liczebność zamieszkujących je populacji.

\footnotetext{
${ }^{26}$ Podobne spisy pruskie budzą w części wypadków duże wątpliwości. Za przykład posłużyć tu mogą tabele miast wydane przez Stefana Cackowskiego, według których w roku 1793 przeciętne zaludnienie domu w Radziejowie wynosić miało 2,9 mieszkańca (Stefan Cackowski, Miasta dobrzyńskie i kujawskie w końcu XVIII i na początku XIX wieku (1793-1807), Włocławek 1995, s. 46). Podany w tabeli 2 wynik analizy spisu ludności z roku 1791 wyniósł zaś 5 ,4. Co ważne, liczba budynków zarejestrowanych w obydwy źródłach jest niemal identyczna. Zaskakująco niskie wartości pojawiły się też w kilku innych ośrodkach ujętych w pruskich tabelach miast.

${ }^{27}$ Łukasz Jewuła, Galicyjskie miasta i miasteczka oraz ich mieszkańcy w latach 1772-1848, Kraków 2013, s. 173-245.

${ }^{28} \mathrm{~W}$ przypadku niemal wszystkich miast powiatu stryjskiego dane pochodzą z roku 1786. W odniesieniu do nich brak też informacji dotyczących roku 1824.
} 
Tabela 3. Przeciętne zaludnienie domów w miastach galicyjskich w latach 1787 i 1824

\begin{tabular}{lccccccc}
\hline \multirow{2}{*}{$\begin{array}{c}\text { Liczba } \\
\text { domów }\end{array}$} & \multicolumn{4}{c}{ Galicja 1787 } & \multicolumn{3}{c}{ Galicja 1824 } \\
\cline { 2 - 7 } & średnia & minimum & maksimum & $\begin{array}{c}\text { współczynnik } \\
\text { zmienności }\end{array}$ & $\begin{array}{c}\text { liczba } \\
\text { miast }\end{array}$ & $\begin{array}{c}\text { średnia } \\
\begin{array}{r}\text { liczba } \\
\text { miast }\end{array}\end{array}$ \\
\hline do 100 & 6,1 & 4,1 & 8,5 & 15,8 & 31 & 6,6 & 27 \\
$101-200$ & 6,2 & 4,2 & 10,3 & 18,1 & 83 & 6,5 & 68 \\
$201-500$ & 6,3 & 3,8 & 10,7 & 20,8 & 111 & 6,3 & 153 \\
$501-1000$ & 6,1 & 4,4 & 7,7 & 18,9 & 20 & 6,4 & 28 \\
$1001-2000$ & 9,9 & 5,2 & 14,6 & 67,5 & 2 & 7,1 & 10 \\
$2001+$ & 12,1 & 12,1 & 12,1 & - & 1 & 20,4 & 1 \\
\hline
\end{tabular}

Źródło: Łukasz Jewuła, Galicyjskie miasta i miasteczka oraz ich mieszkańcy w latach 1772-1848, Kraków 2013, s. 173-245.

Widoczne w tabeli średnie wskazują na znaczną jednorodność miast mających nie więcej niż 1000 budynków. W czterech grupach, na które podzielone zostały takie miasta, przeciętne zaludnienie domu wynosi nieco ponad 6 osób. Także miary rozkładu, w tym przede wszystkim współczynniki zmienności, nieznacznie tylko różnią się między sobą. Dopiero w przypadku miejscowości większych dostrzec można wyższe średnie. Szczególnie wyróżnia się tu Lwów (liczący według źródła 2695 budynków). Pewne trudności interpretacyjne sprawiają natomiast miejscowości zaliczone do grupy przedostatniej: Brody (1157 domów) i Jaworów (1084). Choć ich wspólna średnia, wynosząca 9,9 mieszkańca na budynek, dobrze wpisuje się w opowieść o powiązaniu zaludnienia domów $\mathrm{z}$ wielkością miast, to została ona wyliczona dla dwóch poważnie różniących się ośrodków - w znacznie ludniejszych Brodach w budynku przebywało przeciętnie 14,6 osób (czyli więcej niż we Lwowie), gdy tymczasem w Jaworowie tylko 5,2 . Wynika stąd, że w celu precyzyjnego szacowania zaludnienia należałoby brać pod uwagę inne czynniki związane przede wszystkim z charakterem ośrodka oraz rodzajem dominującej w nim zabudowy. Na to, że miasta mogły dość wyraźnie różnić się ze względu na przeciętną liczbę mieszkańców przypadającą na dom, wskazują także dane zaprezentowane na wykresie 2. Widoczne na nim rozkłady gęstości wartość minimalną osiągają w roku 1787 przy średniej wynoszącej zaledwie 3,8 (Gliniany w cyrkule złoczowskim), gdy tymczasem wartość maksymalną równą 14,6 zarejestrowano we wspomnianych już Brodach. Wynika stąd, że choć większość obserwacji skupiała się w okolicy średniej 6 i raczej nie wykraczała poza 5 i 7, możliwe tu były pewne odstępstwa, zarówno w górę (co dotyczyło przede wszystkich miast większych), jak i w dół. Wyjaśnienie przyczyn pojawiania się niektórych zaskakująco niskich wartości wymagałoby dokładniejszych studiów. Być może w części przypadków doszło do zwyczajnych 
pomyłek podczas rejestracji danych ${ }^{29}$, ale nie można też wykluczać wpływu czynników takich jak pożary, epidemie czy perturbacje ekonomiczne prowadzących do spadku zaludnienia niektórych miast. Równocześnie należy jednak zauważyć, że zarówno rozkłady gęstości, jak i średnie zaprezentowane w tabeli 3 wskazują na generalną trwałość badanego zjawiska. Między rokiem 1787 a 1824 nie doszło do znacznych zmian w przeciętnym zaludnieniu domów, a jedyny wyjątek od tej prawidłowości stanowią miasta duże, w tym przede wszystkim Lwów ${ }^{30}$. Skoro obserwowane wartości utrzymywały się w kolejnych tabelach miast, można mieć nadzieję, że wykorzystywane tu źródło oddaje rzeczywiste prawidłowości, wykraczające poza jeden specyficzny rok lub pojedynczą instrukcję spisową ${ }^{31}$. Nawet jeśli nie zawsze trzeba wierzyć w informacje dotyczące poszczególnych miast, to już wartości średnie wyliczone dla całych grup powinny być odporne na pojedyncze pomyłki. Co więcej, skoro przeciętne zaludnienie budynków nie ulegało istotnym zmianom między wiekiem XVIII a XIX, wzrasta też szansa, że zaobserwowane prawidłowości dotyczyły także okresu wcześniejszego.

Przeprowadzoną analizę rozkładów przeciętnego zaludniania domów, wskazującą na potencjalną użyteczność przelicznika wynoszącego 6, poprzeć można dzięki regresji liniowej. Przedstawione w tabeli 4 modele ${ }^{32}$ stanowią próbę przewidzenia średniego zaludnienia domów przy pomocy kilku zmiennych dostępnych w zachowanym materiale źródłowym. Obok już wcześniej wykorzystywanej liczby domów ${ }^{33}$, uwzględniono rodzaj własności miasta oraz, w odniesieniu do roku 1824, procent Żydów wśród jego populacji. Własność pogrupowana zo-

${ }^{29}$ Co ciekawe, w roku 1799 średnie zaludnienie domu w Glinianach wynosić już miało 5,1 mieszkańca. Podobne wzrosty nastąpiły też w innych, wcześniej najgorzej wypadających miastach. Równocześnie jednak niektóre ośrodki doświadczyły poważnych spadków. Zazwyczaj, jak w przypadku Kopczyńc w cyrkule czortkowskim, wynikało to z wzrostu liczby domów przy równoczesnym braku przyrostu populacji, ale pojawiały się też miasta takie jak Buczacz, gdzie, wedle austriackiej statystyki, miało ubyć 125 budynków (spadek o 18\%) i aż 1940 mieszkańców (redukcja o 38\%).

${ }^{30}$ Spadek średniej zaludnienia wyliczonej dla kategorii 1001-2000 domów wynika przede wszystkim z jej liczebnego wzrostu. Podczas gdy w roku 1787 obejmowała ona tylko dwa ośrodki, 37 lat później pojawiło się w niej osiem dalszych miast. Niektóre z nich, jak na przykład Kołomyja, charakteryzowały się bardzo niskim zaludnieniem i obniżyły wartości wyliczone dla całej grupy.

${ }^{31}$ Podobne wartości, oscylujące w okolicach średniej 6 mieszkańców na dom, dotyczą także danych pochodzących z nieomówionych tu lat 1799, 1807 i 1816.

${ }^{32}$ Ze względu na naszą niechęć do p-value, postanowiliśmy w jej miejsce podawać $95 \%$ przedziały ufności, które w naszej opinii znacznie bardziej przydają się do opisu i analizy miar statystycznych. Na zalety takiej praktyki zwrócono ostatnio uwagę w oświadczeniu American Statistical Association - ASA Statement on Statistical Significance and P-values, red. Ronald L. Wasserstein, DOI:10.1080/00031305.2016.1154108.

${ }^{33}$ Dla wygody interpretacji zdecydowaliśmy się na wprowadzenie do modeli niezlogarytmizowanej liczby domów. Dokładniejsze analizy wykazały zresztą, że zastosowanie logarytmów, co byłoby zapewne właściwsze pod względem obliczeniowym choć równocześnie mniej przyjazne z punktu widzenia czytelników, nie zmieniłoby uzyskanych tu wyników. 
stała na trzy kategorie: prywatną, duchowną oraz państwową. Do tej ostatniej zostały zaliczone miasta określone w źródle jako kameralne i królewskie.

Wykres 2. Rozkład przeciętnego zaludnienia domów w miastach galicyjskich w latach 1787 i 1824

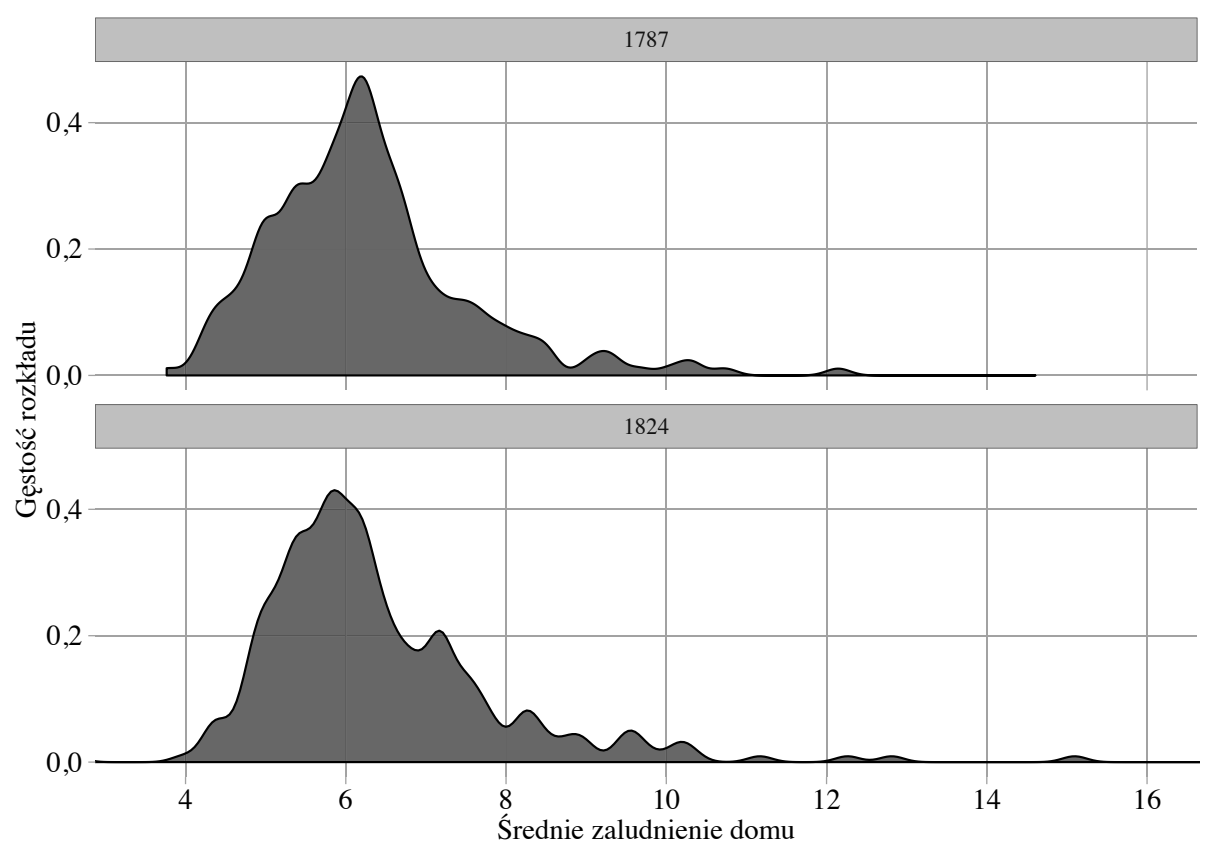

Źródło: patrz tabela 3.

Czytelnik łatwo zauważy, że wartość predykcyjną ma jedynie pierwszy z zaprezentowanych $w$ tabeli modeli, który opisuje przeciętne zaludnienie domów we wszystkich miastach Galicji w roku 1787. Wynika z niego, że wraz ze wzrostem liczby budynków wzrasta też średnie ich zapełnienie. Jednak wpływ ten okazuje się nieznaczny (wystarczy tu podkreślić, że aby go oddać, musieliśmy podać wartości do trzeciego miejsca po przecinku), a procent wariancji wyjaśnionej przez cały model także jest niewielki (skorygowane $\mathrm{R}^{2}$ to zaledwie $4,3 \%$ ). Czytelnik zaznajomiony już z zawartością tabeli 3 szybko też zauważy, że zaobserwowany wpływ liczby domów na średnią liczbę ich mieszkańców wynika przede wszystkim z występowania w bazie danych stosunkowo gęsto zaludnionych miast największych: Lwowa i Brodów. Skoro ośrodki te ze względu na swoją specyfikę słabo oddają prawidłowości występujące $\mathrm{w}$ większych miejscowościach, ich uwzględnienie w obliczeniach prowadzi do wyników budzących poważne wątpliwości. 
Tabela 4. Modele regresji opisujące przeciętne zaludnienie domów w miastach galicyjskich w latach 1787 i 1824

\begin{tabular}{|c|c|c|c|c|c|c|}
\hline & \multicolumn{2}{|c|}{$\begin{array}{c}\text { Galicja } 1787 \\
\text { (wszystkie miasta) }\end{array}$} & \multicolumn{2}{|c|}{$\begin{array}{c}\text { Galicja } 1787 \\
\text { (miasta do } 1000 \text { domów) }\end{array}$} & \multicolumn{2}{|c|}{$\begin{array}{c}\text { Galicja } 1824 \\
\text { (miasta do } 1000 \text { domów) }\end{array}$} \\
\hline & B & $\begin{array}{c}\text { przedział } \\
\text { ufności }\end{array}$ & B & $\begin{array}{l}\text { przedział } \\
\text { ufności }\end{array}$ & B & $\begin{array}{l}\text { przedział } \\
\text { ufności }\end{array}$ \\
\hline Stała & 5,90 & $5,40-6,39$ & 6,42 & $5,94-6,89$ & 6,28 & $5,73-6,83$ \\
\hline Liczba domów & 0,001 & $0,001-0,002$ & $-0,00$ & $-0,00-0,00$ & $-0,00$ & $-0,00-0,00$ \\
\hline Procent Żydów & & & & & 0,01 & $-0,00-0,02$ \\
\hline \multicolumn{7}{|l|}{ Własnośća: } \\
\hline prywatna & 0,08 & $-0,38-0,54$ & $-0,10$ & $-0,52-0,32$ & $-0,03$ & $-0,48-0,43$ \\
\hline kościelna & $-0,19$ & $-0,96-0,59$ & $-0,35$ & $-1,06-0,35$ & $-0,25$ & $-1,04-0,55$ \\
\hline Obserwacji & \multicolumn{2}{|c|}{247} & \multicolumn{2}{|c|}{244} & \multicolumn{2}{|c|}{274} \\
\hline $\mathrm{R}^{2} /$ skor. $\mathrm{R}^{2}$ & \multicolumn{2}{|c|}{, $055 /, 043$} & \multicolumn{2}{|c|}{, $005 /-, 007$} & \multicolumn{2}{|c|}{, $015 /, 000$} \\
\hline
\end{tabular}

${ }^{a}$ Kategorią odniesienia jest własność państwowa.

Źródło: patrz tabela 3.

W celu uniknięcia takich problemów w modelu drugim $\mathrm{z}$ analizy wyłączono miasta posiadające więcej niż tysiąc budynków. Rezultatem naszego działania okazuje się być model, w którym wszystkie współczynniki są nieistotne. Ani liczba domów, ani rodzaj własności nie wpływają na przeciętne zaludnienie. Właściwie identyczny wynik uzyskany został także w modelu wyliczonym dla roku 1824. Przy pominięciu miast największych, zabudowa, własność oraz procent Żydów okazują się nieistotne, a cały model wyjaśnia $0 \%$ wariancji zmiennej zależnej.

Uzyskane rezultaty, wskazujące na całkowitą nieużyteczność modeli oraz brak wpływu rodzaju własności, udziału Żydów w populacji oraz liczby domów (do tysiąca) na przeciętne zaludnienie, prowadzą do bardzo rzadkiej sytuacji, gdy brak istotności staje się źródłem zadowolenia autorów. Wyniki te potwierdzają bowiem po raz kolejny znaczenie współczynnika wynoszącego 6 osób na budynek przy obliczaniu zaludnienia miast. Czytelnicy łatwo zauważą, że stałe we wszystkich modelach są do tej wartości bardzo zbliżone i jako jedyne okazują się istotne. Konstatacja ta pozwala nam na ostateczne sformułowanie propozycji dotyczącej przeliczników zaludnienia.

Sądzimy, że w przypadku ośrodków mniejszych, charakteryzujących się przede wszystkim drewnianą zabudową, najwłaściwszym przelicznikiem służącym do szacowania liczby ich mieszkańców będzie 6 osób na dom. Wartość taka $\mathrm{z}$ całą pewnością obciążona będzie pewnym błędem, ale powinna, mimo wszystko, w przybliżeniu oddawać stan rzeczywisty. Równocześnie jednak przy szacunkach takich pamiętać należy o znaczeniu czynników dodatkowych, w tym przede wszystkim o charakterze zabudowy danego miasta oraz występowaniu 
w nim różnorakich instytucji. Jak wyraźnie wynika z zaprezentowanych w tabeli 1 danych krakowskich, budynki murowane miały przeciętnie większą liczbę mieszkańców. Zjawisko to jeszcze wyraźniej można dostrzec w przypadku wszelkiego rodzaju instytucji.

\section{Inne przeliczniki}

W przypadku nieznanej skali zabudowań, autorzy odpowiednich opracowań w serii Atlasu Historycznego Polski, idąc za sugestiami Ireny Gieysztorowej, odwoływali się do pewnych kategorii ludności miejskiej: rzemieślników, kupców, przekupniów i komorników oraz łanów miejskich, o których informują rejestry poborowe. Niestety, duży wpływ na dokładność rejestrów mają zwyczaje poborców podatkowych i nie zawsze wszystkie zaprojektowane przez uniwersały kategorie podatkowe są wyodrębnione w źródle (i tam, gdzie to możliwe, warto sięgnąć do rekognicji). Dane tego rodzaju, zwłaszcza dla miast królewskich i kościelnych, można uzyskać także z materiałów o charakterze inwentarzowym. Oczywiste jest, że liczba ludności rzemieślniczo-handlowej oraz komorników i mieszczan uprawiających rolę może być podstawą jedynie bardzo orientacyjnych szacunków stanu populacji miejskiej, gdyż stanowili oni ważne, ale nie wszystkie miejskie grupy społeczno-zawodowe. Dodatkowo w kalkulacjach musimy uwzględnić liczebność gospodarstw domowych rzemieślników, przekupniów, komorników, jak i mieszczan uprawiających rolę, a w przypadku tych ostatnich powiązać ją $\mathrm{z}$ opodatkowanym areałem ziemi.

Badania nad wielkością miejskich gospodarstw domowych ze względu na dostępność materiałów źródłowych skupiają się na osiemnastym wieku, ale uzyskiwane wyniki wskazują na olbrzymie zróżnicowanie w tej dziedzinie, zależne od wielkości ośrodków miejskich i struktury społecznej. W największych miastach, takich jak Warszawa czy Kraków przeciętne gospodarstwa zamożnych mieszczan liczyły powyżej 7 osób, ale już w warstwach średnich najbardziej typowe były gospodarstwa około 5-osobowe, zaś wśród najbiedniejszych były jeszcze mniejsze, liczące około 3,6 osoby na gospodarstwo ${ }^{34}$. Mniejsza liczebność gospodarstw domowych pod koniec XVIII wieku była charakterystyczna dla małych ośrodków miejskich. Według badań Cezarego Kukli w takich miejscowościach jak Olkusz, Praszka, Radziejów i Wieluń gospodarstwa liczyły średnio 4-5 osób ${ }^{35}$.

Związek między pozycją społeczną (i zamożnością) a wielkością gospodarstw domowych zaobserwowali też demografowie historyczni zajmujący się

\footnotetext{
${ }^{34}$ Cezary Kuklo, Kobieta samotna w społeczeństwie miejskim u schytku Rzeczypospolitej szlacheckiej. Studium demograficzno-społeczne, Białystok 1998, s. 129-132.

${ }^{35}$ Tamże, s. 126-127.
} 
okresem wcześniejszym. Stanisław Borowski analizując strukturę populacji mieszkańców warmińskiego Dobrego Miasta w 1695 roku, wyliczył, że patrycjuszowskie gospodarstwa domowe liczyły przeciętnie 8,6 osoby, rzemieślnicze 5 osób, a komornicze $-3^{36}$. Z kolei Anna Laszuk ustaliła, że w 12 miastach podlaskich w 1662 roku przeciętne gospodarstwo domowe liczyło 3,3 osoby powyżej 10. roku życia ${ }^{37}$. Jedyne badania dotyczące mieszczańskich gospodarstw domowych w XVI wieku przeprowadził Stanisław Waszak, analizujący zachowany sumaryczny spis pogłównego mieszkańców Poznania z 1590 roku, według którego gospodarstwa wieloosobowe liczyły przeciętnie 5,6 mieszkańców, przy czym zamieszkujące przy rynku były większe, osiągając średnio 7,1 osoby. Pamiętać należy jednak, że w mieście było bardzo dużo gospodarstw jednoosobowych. Po ich doliczeniu zaludnienie przeciętnego gospodarstwa spadło poniżej 5 osób ${ }^{38}$. Wszystkie te wartości są znacznie mniejsze od proponowanych przez Marię Bogucką, która opisując gospodarstwa patrycjuszowskie Warszawy czy Gdańska wskazywała na $8-10$, a 20-osobowy ich skład ${ }^{39}$. Optymalnym rozwiązaniem będzie więc przyjęcie przelicznika 5 osób na jednego płatnika z mieszczańskich grup rzemieślniczo-handlowych oraz 3 osób na jednego zarejestrowanego komornika.

Do wymienionych mieszczan zajmujących się działalnością rzemieślniczą i handlową należy doliczyć mieszkańców uprawiających role. W tym wypadku należy przyjąć przeliczniki charakterystyczne dla terenów wiejskich. Jeśli dzięki porównaniu rejestrów poboru z lat 1552 i 1563 da się ustalić przeciętną wielkość areału będącego w dyspozycji gospodarstwa, wówczas - zgodnie z przyjętymi wyżej zasadami - gospodarstwom do ćwierci łanu powinny odpowiadać 4 osoby, a każde kolejne 0,25 włóki wymagałoby doliczenia jednej osoby w przeciętnym gospodarstwie ${ }^{40}$.

\footnotetext{
${ }^{36}$ Stanisław Borowski, Próba odtworzenia struktur społecznych i procesów demograficznych na Warmii u schytku XVII w. na przykładzie Dobrego Miasta i okolicy, „Przeszłość Demograficzna Polski" 8, 1975, s. 146.

${ }^{37}$ Anna Laszuk, Ludność województwa podlaskiego w drugiej połowie XVII wieku, Warszawa 1999, s. 109.

${ }^{38}$ Stanisław Waszak, Ludność i zabudowa mieszkaniowa Poznania w XVI i XVII wieku, „Studia Poznańskie” 2, 1954, s. 140-141. Zaznaczyć jednak należy, że w źródle nie rejestrowano szlachty i duchowieństwa, czyli grup mogących zapewne taką średnią nieco zawyżyć.

${ }^{39}$ Maria Bogucka, Rodzina w polskim mieście XVI-XVII wieku: wprowadzenie w problematykę, „Przegląd Historyczny” 74, 1983, z. 3, s. 499.

${ }^{40}$ Zob. w niniejszym numerze tekst K. Borody, P. Guzowskiego, Przeliczniki demograficzne w szacunkach zaludnienia terenów wiejskich $w$ Królestwie Polskim $w$ drugiej połowie XVI wieku.
} 


\section{Podsumowanie}

W świetle zaprezentowanych rozważań należy przyznać, że w przypadku ludności miejskiej w drugiej połowie XVI wieku możemy mówić jedynie o przybliżonych szacunkach, opartych na bardzo niedoskonałej podstawie źródłowej. Spośród 861 miast funkcjonujących na terenie Korony większość ośrodków należało do trzeciej i czwartej kategorii podatkowej, w której budynki murowane odgrywały marginalne znaczenie ${ }^{41}$. Dlatego w sytuacji znanej nam liczby budynków warto posłużyć się przelicznikiem 6 , wynikającym ze statystyki mieszkańców i domów miast galicyjskich w końcu XVIII wieku. W wypadku większych ośrodków można liczyć też na lepszą, związaną z kancelarią miejską dokumentacją źródłową, która niejednokrotnie zaowocowała szacunkami dostępnymi w dotychczasowej historiografii. Brak danych dotyczących budynków skazuje nas na informacje zawarte w rejestrach poborowych. Wyszczególnione w nich kategorie ludności i łanów miejskich również mało precyzyjnie, ale jednak, pozwalają na orientacyjne oszacowanie liczby ludności.

\section{Demographic Conversion Factors in the Assessments of Urban Population in the Kingdom of Poland in the Second Half of the $16^{\text {th }}$ Century}

\section{Summary}

The article presents the methods of computing the size of urban population in the Kingdom of Poland in the second half of the $16^{\text {th }}$ century. As there are no sources such as censuses the assessments of the population have had to be carried out on the basis of indirect sources, which cannot be precise. The most popular method of computing the size of urban population consists in counting the buildings situated in the town in question, which had been registered in inventory or tax sources. The authors analysing the date of the whole early modern period, especially the $18^{\text {th }}$-century Austrian registers have come to the conclusion that the value of the conversion factor should be related to the type of buildings. In the case of most Polish towns dominated by wooden buildings the conversion factor should be six people per one house. If we have the information on the number of houses, the calculations of the size of population should be carried out on the basis of the data contained in the land tax collection registers, which register the number of urban mansi and the heads of households of the population composed of craftsmen, tradesmen and landless tenants.

Keywords: population, the Kingdom of Poland, demographic conversion factors, urban population

\footnotetext{
${ }^{41}$ Maria Bogucka, Henryk Samsonowicz, Dzieje miast i mieszczaństwa w Polsce przedrozbiorowej, Wrocław 1986, s. 120, 330.
} 